\title{
The Russian Academy of Sciences and its Institutions.
}

THE Russian Academy of Sciences, representing as it does the highest seat of learning in all its branches in the State, consists of a large number of affiliated institutions, and a survey of them, recently published by the Academy, is of wide interest to all men of science. The interest is not affected by the fact that the survey has been prepared for a specific purpose, namely, for the occasion of the tenth anniversary of the Soviet government, with the view of showing the world the effect that the Revolution has had on Russian science. The volume consists of a series of chapters dealing with each institution separately, and we will follow this arrangement. Each chapter concludes with a bibliography of papers and books dealing with the particular institution, and with a list of scientific and technical staff.

The Library of the Academy was founded by Peter the Great, who brought a number of foreign books home from his travels. At first it functioned as a public library, but with the foundation in 1812 of a special Public Library in St. Petersburg it was transformed into a purely academic library. In 1924 a new building was completed for the library, with a floor space of $12,500 \mathrm{sq}$. metres. The number of titles of books and manuscripts in the library is more than three millions; the staff numbers 170 .

The Steklov Physico-Mathematical Institute doveloped from the first Russian scientific laboratory, apparatus for which was actually acquired by Peter the Great before the Academy was founded. At first it was called the Physical Laboratory, and amongst its directors have been E. Lentz, B. S. Jacoby, O. D. Chwolson, B. B. Galitzine. The last-named started highly important work on seismology, and it is due to him that the Russian seismological service was developed, but during the civil war and the Revolution it was almost wholly destroyed, and only now are steps being taken to re-establish it. The Physical Laboratory during that time also practically ceased to function. In 1921 the mathematical cabinet was founded under the directorship of V.A. Steklov, and in the same year it was united with the Physical Laboratory to form the present Physico-Mathematical Institute, which was named after V. A. Steklov when the latter died in 1926. At present the institute consists of three departments : mathematical, physical, and seismic ; the present director is A. F. Joffé.

The Chemical Institute developed from the chemical laboratory founded in 1748 by Lomonosov, one of the first Russian chemists, and such well-known chemists as Frizsche, Zinin, Butlerov, and others have worked in it. In 1924 the laboratory was transformed into the Chemical Institute with two departments : general and organic chemistry, high pressures and high temperatures. In connexion with the Institute are working some of the institutes of the Commission for the Study of Natural Resources (see below). The department of general chemistry under N. S. Kurnakov is working at present mainly on problems of physico-chemical analysis, pure and as applied to the study of ores and minerals. The second department, under V. N. Ipatiev, is studying the action of high pressures and temperatures on chemical compounds.

The Dokutchaev Soil Institute began its activities in 1881 as an independent.public committee under V. V. Dokutchaev and later under K. D. Glinka, who. has recently died ( $v$. Nature, Dec. 17, 1927, p. $887)$. Since 1918 it has been incorporated into the

I Scientific Institutions of the Academy of Sciences, U.S.S.R Leningrad, 1927. Pp. $169+17$ plates.

No. 3046, VoL. 121]
Academy, and at present it consists of a soil museum, department of soil cartography, department of soil surveys, and a department for the study of the dynamics of soil formation.

The Physiological Institute was founded in 1889 as a laboratory, and is at present under the directorship of I. P. Pavlov; its work is mainly on the problems of reflexes, and the physiology of brain generally.

The Yafetic Institute is one of the recently founded (1921) branches of the Academy, and its work consists in research on Yafetic languages of the original population of Europe. The director of the Institute is N. J. Marr.

The Laboratory of Biochemistry and Plant Physiology has been in existence since 1889. Its present director is S. P. Kostychev, and the work is mainly concentrated on biochemistry of fermentation, photosynthesis, fixation of atmospheric nitrogen, and mineral nutrition of plants.

The Special Zoological Laboratory, founded by A. O. Kovalevsky in 1893, was considerably enlarged in 1921 under the directorship of N. V. Nasonov, and is working on different branches of morphology and experimental zoology.

The Geological Museum was originally a part of the Kunstkamera founded by Peter the Great. In 1913 funds were obtained for a large new building, but the War prevented its erection, and it was not until 1922 that the Museum obtained new premises for development. At present only some of the galleries are open to the public, but scientific work is being carried out in all directions, under the directorship of F. J. Levinson-Lessing.

The Mineralogical Museum originated in the same way as the Geological Museum. It has now six exhibition galleries and scientific laboratories guided by A. E. Fersman. During the last ten years numerous expeditions have been organised by the Museum for studying mineral resources of outlying parts of Russia.

The Botanical Museum was also founded by Peter the Great. There are no exhibition galleries, the Museum consisting entirely of herbaria, occupying twelve halls. Research work is being conducted mainly in the Caucasus, Siberia, and Northern Russia. The present director is I. P. Borodin.

The Zoological Museum has existed since 1832 as a special institution, and consists of public galleries and scientific departments, under the direetorship of A. A. Birula. The scientific staff includes 35 workers. Expeditions for the zoological survey of various parts of Russia are being organised more extensively than in the past, and collections from the Palæarctic region are enormous in size. There are, however, difficulties in publishing the results of scientific work. Exhibition galleries occupy two large halls.

Pushlin House is a museum for preserving all relics connected with the great national poet, for scientific research on Pushkin, and on the history of Russian literature generally. It has a remarkable collection of manuscripts, a library, and public museum. The present director is S. F. Platonov.

The Museum of Anthropology and Ethnography again developed as a part of the Kunstkamera. It represents the central place for all research on anthropological and ethnographical problems, and consists of laboratories and public galleries, under the directorship of E. F. Karsky.

The Asiatic Museum is rather a library than a museum, since all ethnographical objects have been 
transferred to the corresponding museum, and the main aim of the Asiatic Museum is collecting and studying literature, both printed and manuscript, on oriental problems; it has probably the richest collection in the world on oriental studies. The Museum is under the directorship of S. F. Oldenburg.

The Museum of Palcoography was founded in 1925 and has as its aim a full representation of systems of writing, from the ancient inscriptions on monuments to the present-day printing technique. The Museum is still in course of organisation.

The Commission for the Study of Natural Resources was founded in 1915 on the initiative of its present president, V. I. Vernadsky, with the view of studying systematically the natural resources of Russia. The main directions of work are defined as : unification and consolidation of local work on the study of natural resources; independent field research; description of separate regions from the point of view of their resources; research in the practical utilisa. tion of natural resources. In accord with its diversity of functions, the Commission has a number of working branches, as follow: Institute of Physico-Chemical Analysis, working on analyses of salt deposits in the Caspian Sea, metallic ores, etc.; Institute for the Study of Platinum and other Noble Metals, studying methods of analysis of platinum ores and the extraction of the metal from them; Section of Non-Metallic Minerals and Gems, which has published a series of monographs on asbestos, sulphur, etc., as well as on gems and valuable stones; Section of Stone Building Materials, which is studying building materials from the point of view of their distribution in Russia, and from the technical aspect as well; the Sapropelite Committee, which is engaged in studying lake deposits and their utilisation; the Gaseous Section, which studies natural gases, mainly from the point of view of the presence in them of helium for aviation purposes ; the Section of Energetics is preparing a register of natural power resources, mainly of water, but also of wind and tides; the Geographic section is mainly engaged in research on problems of economic geography; the Bureau of Genetics studied at first problems of heredity in man, but at present it is engaged in work on heredity in wheat, domestic animals, etc.; Section for the Study of Living Substance, under V. I. Vernadsky, is engaged on problems of the influence of organic matter on geo- chemical processes; the Moscow section of the Commission has also several laboratories-for genetics, applied zoology, etc.

The Commission for the Study of Nationalities occupying Russia is studying the population, preparing maps, studying habits of various national groups, their occupations, etc.

The Commission for Scientific Expeditions is intended to correlate expeditions sent out by various institutions of the Academy. The number of expeditions has increased greatly during recent years, and for the last ten years (1917-1927) their number exceeded two hundred.

The Special Committee for the Study of Allied and Autonomous Republics was founded in 1926 in order to direct and co-ordinate surveys organised by the Academy at the request of republics. The committee is organising expeditions into Kazakstan (Kirghiz steppes), Karakum desert, Armenia, and other parts.

The Commission for the Study of the Yakut Republic was formed at the request of the said republic for a comprehensive survey of its natural resources. The work is calculated to take five years, and preliminary results have already been published.

The Commission for Science and Scientific Workers is preparing registers of all scientific workers in Russia, which it is intended to publish regularly.

The Polar Commission was founded in 1914 for co-ordination of work in polar countries done by different bodies. Its activities have developed only since 1923, and in 1925 an expedition to Novaya Zemlya was organised.

The Historico-archoographical Commission is dealing with the publication of historical documents and manuscripts on nationalities of Russia.

The Dictionary Commission has existed since 1922, and is preparing materials for a dictionary of the Russian language, which is being published.

The publications of the Academy and its institutions are produced in the Academy's printing office. Its publishing activities suffered much during the years of revolution, and at present the pre-War level is still not reached. Publications are distributed by the Academy book-store and the Bureau for International Exchanges. Interruption of exchanges was severely felt by the Academy, but at present exchanges are approaching normal.

\section{The Glacial Retreat from Central and Southern Ireland. ${ }^{1}$}

\section{By Prof. J. K. Charlesworth.}

$\mathrm{T}^{\mathrm{H}}$ HE newer drift of Ireland is bounded on the south by a broad and well-developed kettle-moraine -the 'South Irish End-moraine'-which runs from the vicinity of Wexford round the northern flanks of the Dublin hills and by way of Baltinglass, Bennettsbridge, Cahir, Tipperary, Charleville, and Newcastle West to the mouth of the Shannon, a distance of 310 miles from coast to coast.

Contemporaneous with this stage of the Ivernian ice and the Irish Sea ice were the independent icecentres in the Kerry and Wicklow Hills, the Comeraghs, Galtees, Knockmealdown, and other mountain clusters of the south. Their extent is likewise indicated by wellmarked outer moraines, and corresponds to a snow-line on northern and eastern slopes of about 1000 feet and on other slopes of approximately twice that altitude.

The Irish glacial fauna is restricted, with but few exceptions, to the region outside these moraines.

The ice recession from the Dublin and Wicklow Hills

1 Substance of a communication read before the Geological society on Jan. 25 .

No. 3046, VoL. 121] is clearly shown by moraines and marginal drainagefeatures. These prove a pivoting of the ice on the northern slopes of the hills, immediately south of Dublin, and the sweeping of the ice-fronts to east and west, at successive stages of the retreat, in a series of curves which swing out of each other tangentially and northwards.

The dissolution of the Ivernian ice-sheet caused the emergence of the higher hills, such as the Castlecomer Plateau, the Slieve Bloom, and Keeper Hills, and the formation of large lobes protruded southwards down the intervening valleys. The moraines of the Barrow, Nore, Suir, Shannon, and other lobes are magnificently displayed, making possible the correlation frorn lobe to lobe and the delineation of the successive positions of the ice margin across the country from coast to coast. The festooning of the moraines in the southern part of the country is governed by the relief, while their sinuous form in the northern region is to be ascribed to the break-up of the ice-sheet into separate lobes, flowing on roughly parallel lines. 